\title{
Erkältungskrankheiten - wie viel Antibiotika brauchen wir?
}

\author{
Wolfgang Kamin \\ Klinik für Kinder- und Jugendmedizin, Evangelisches Krankenhaus Hamm, Hamm, Deutschland
}

Akute Atemwegsinfektionen gehören weltweit zu den häufigsten Erkrankungen. Dabei sind rund 90\% aller akuten Infektionen der oberen und unteren Atemwege viraler Ursache. Obwohl Antibiotika bei Virusinfekten keine Wirksamkeit zeigen, werden diese zur Behandlung weiterhin viel zu häufig eingesetzt. Dies könnte unter anderem damit zusammenhängen, dass der Effekt einer antibiotischen Behandlung bei Erkältungskrankheiten überschätzt wird [1]. Hier gilt jedoch: Eine Pneumonie auszuschliessen ist wichtig - bei Patienten ohne Herz- oder Lungenerkrankung, bei Patienten ohne Immunsuppression in der Vorgeschichte sowie bei Patienten, die kürzer als eine Woche krank sind, ist eine Antibiotikatherapie bei einem unkomplizierten Atemwegsinfekt jedoch von geringem Nutzen [2].

Aktuelle Daten einer in Deutschland, Grossbritannien, Dänemark und den Niederlanden durchgeführten Kohortenstudie weisen darauf hin, dass besonders die Gruppe der unter Vierjährigen überdurchschnittlich hohe Antibiotika-Verschreibungsraten aufweist [3]. Aus dem beobachteten Anstieg der Verschreibungen in den Wintermonaten Dezember bis März schliessen die Autoren auf eine häufige Anwendung bei überwiegend viralen Infekten. Eine solche gehäufte unkritische Verabreichung von Antibiotika birgt jedoch ein erhöhtes Risiko für Resistenzbildungen [4, 5], die weltweit zu den grössten infektiologischen Problemen gehören. Auch konnte in einer Studie gezeigt werden, dass Kinder, die bereits sehr früh mit Antibiotika behandelt werden, im Alter von 7 Jahren 2,5-mal häufiger an Asthma leiden und häufiger eine Allergie entwickeln als Kinder ohne Antibiotika-Verabreichung [6]. Antibiotika sollten daher bei Erkältungskrankheiten nur gemäss den geltenden medizinischen Leitlinien verordnet werden und sind für die Mehrzahl der Fälle - sofern es sich nicht um eine Lungenentzündung handelt - nicht erforderlich.

Dies zeigt einen grossen Bedarf an Präparaten auf, welche eine gute Wirksamkeit und Verträglichkeit bei der Behandlung von viralen Atemwegserkrankungen aufweisen. Hier bieten sich pflanzliche Arzneimittel an, wie z.B. Präparate mit Extrakten oder Ölen aus den Arzneipflanzen Pelargonium sidoides, Thymian, Primel, Eukalyptus oder Efeu.
In verschiedenen Ländern wird zur Behandlung von Atemwegsinfekten z.B. häufig $\mathrm{EPs}^{\circledR} 7630$ (Wirkstoff des pflanzlichen Arzneimittels Umckaloabo ${ }^{\circledR}$ (ISO Arzneimittel, Ettlingen, Deutschland), in der Schweiz als Kaloba (Schwabe Pharma) im Handel) eingesetzt, ein Auszug aus Wurzeln von P. sidoides (1:8-10); Auszugsmittel: Ethanol 11\% (m/m) [7]. Wie in präklinischen Studien [8-12] gezeigt werden konnte, besitzt EPs 7630 einen multifaktoriellen Wirkmechanismus, wobei die Wirkung auf antiviralen, antibakteriellen, immunomodulatorischen sowie sekretomotorischen und sekretolytischen Eigenschaften beruht.

Auch im Rahmen klinischer Studien mit Kindern bzw. Erwachsenen wurde eine Therapie mit EPs 7630 bei unterschiedlichen akuten Atemwegsinfektionen intensiv geprüft und als wirksam und gut verträglich beurteilt [7, 13-28]. So wurden z.B. in einer vierarmigen Dosisfindungsstudie 399 Kinder und Jugendliche (Alter 6-18 Jahre) mit akuter Bronchitis ohne zwingende Indikation für eine Antibiotikatherapie mit täglich $3 \times 10 \mathrm{mg}, 3 \times 20 \mathrm{mg}$ bzw. $3 \times 30 \mathrm{mg}$ EPs 7630 oder Placebo behandelt [21]. Im Ergebnis zeigte sich nach einer Therapiedauer von 7 Tagen für die beiden höheren Dosierungen eine im Vergleich zu Placebo statistisch signifikante und klinisch relevante Verbesserung des Gesamtscores, des validierten Bronchitis Severity Scale (BSS) [29]. Insgesamt kam es bei den mit EPs 7630 behandelten Patienten zu einem günstigeren Krankheitsverlauf und einer schnelleren Erholung; die Verträglichkeit war in allen drei EPs-7630-Gruppen mit Placebo vergleichbar. Auch in zwei weiteren doppelblinden, placebokontrollierten, multizentrischen klinischen Prüfungen mit insgesamt 420 Kindern und Jugendlichen zwischen 1 und 18 Jahren mit akuter Bronchitis ohne zwingende Indikation für eine Antibiotikatherapie konnte eine statistisch signifikante und klinisch relevante Überlegenheit von EPs $7630 \mathrm{im}$ Vergleich zu Placebo gezeigt werden [20, 22]. Bei gleichzeitig guter Verträglichkeit verbesserte EPs 7630 die Symptomatik der Patienten, erhöhte die Lebensqualität und verringerte die Zahl der Fehltage am Arbeitsplatz und in der Schule. Die Wirksamkeit von EPs 7630 bei akuten Atemwegserkrankungen wurde zudem durch die Ergebnisse systematischer Reviews und Meta-

\section{KARGER}

Fax +497614520714

Information@Karger.com

www.karger.com
Prof. Dr. med. Wolfgang Kamin

Klinik für Kinder- und Jugendmedizin

Evangelisches Krankenhaus Hamm

Werlerstrasse 130, 59063 Hamm, Deutschland

WKamin@evkhamm.de 
Analysen bestätigt [30, 31]. Darüber hinaus konnten die Sicherheit und gute Verträglichkeit von EPs 7630 bei der Behandlung von akuten Atemwegserkrankungen im Rahmen eines systematischen Reviews aller bis zum Jahre 2010 abgeschlossenen klinischen Studien mit Daten von insgesamt 10026 Patienten mit akuten Atemwegserkrankungen, darunter 3939 Kinder und Jugendliche bis 18 Jahre, gezeigt werden [32].

Gerade bei Kindern und Jugendlichen mit banalen Atemwegsinfekten, die keine bekannte schwere Vorerkrankung haben, also bei den meisten pädiatrischen Patienten, ist EPs 7630 damit eine wirksame und gut verträgliche Behandlungsoption.
In der Gesamtbetrachtung ist der Einsatz von Antibiotika bei Erkältungskrankheiten oft nicht gerechtfertigt, da die zugrunde liegenden Infekte meist viraler Natur sind und eine Antibiotikatherapie damit wirkungslos bleibt. Phytopharmaka mit belegter Wirksamkeit und Verträglichkeit, wie z.B. EPs 7630, erscheinen bei akuten Atemwegsinfektionen deshalb als Mittel der Wahl.

\section{Disclosure Statement}

Herr Prof. Kamin erhielt von der Firma Schwabe Pharma Vergütungen für Vortrags- und Beratertätigkeiten.

\section{Literatur}

1 Ebell $\mathrm{MH}$, et al: How long does a cough last? Comparing patients' expectations with data from a systematic review of the literature. Ann Fam Med 2013;11:5-13.

2 Llor C: Acute bronchitis: aetiology and treatment; in Blasi F, Miravitlles M (Hrsg): The Spectrum of Bronchial Infection. European Respiratory Monograph 60. Norwich, Page Bros., 2013, pp 1-17.

3 Holstiege J, et al: Systemic antibiotic prescribing to paediatric outpatients in 5 European countries: a population-based cohort study. BMC Pediatrics 2014;14:174.

4 Malhotra-Kumar S, et al: Effect of azithromycin and clarithromycin therapy on pharyngeal carriage of macrolide-resistant streptococci in healthy volunteers: a randomised, double-blind, placebocontrolled study. Lancet 2007;369:482-490.

5 AKDÄ - Arzneimittelkommission der deutschen Ärzteschaft: Empfehlungen zur Therapie akuter Atemwegsinfektionen und der ambulant erworbenen Pneumonie. Arzneiverordnung in der Praxis 2013; Sonderheft 1 (Therapieempfehlungen).

6 Risnes KR, et al: Antibiotic exposure by 6 months and asthma and allergy at 6 years: findings in a cohort of 1,401 US children. Am J Epidemiol 2011;173:310-318.

7 Chuchalin AG, et al: Treatment of acute bronchitis in adults with a Pelargonium sidoides preparation (EPs $\left.{ }^{\circledR} 7630\right)$ : a randomized, double blind, placebo-controlled trial. Explore 2005; 1: 437-445.

8 Theisen L, Muller CP: EPs ${ }^{\circledR} 7630$ (Umckaloabo $\left.{ }^{\circledR}\right)$, an extract from Pelargonium sidoides roots, exerts anti-influenza virus activity in vitro and in vivo. Antiviral Res 2012;94:147-156.

9 Michaelis M, et al: Investigation of the influence of $\operatorname{EPs}^{\circledR} 7630$, a herbal drug preparation from Pelargonium sidoides, on replication of a broad panel of respiratory viruses. Phytomedicine 2011;18:384-386.

10 Conrad A, et al: Extract of Pelargonium sidoides (EPs 7630) inhibits the interactions of group Astreptococci and host epithelia in vitro. Phytomedicine 2007;14:52-59.

11 Bao Y, et al: Evaluation of pharmacodynamic activities of $\mathrm{EPs}^{\circledR} 7630$, a special extract from roots of Pelargonium sidoides, in animals models of cough, secretolytic activity and acute bronchitis. Phytomedicine 2015;22:504-509.
12 Neugebauer P, et al: A new approach to pharmacological effects on ciliary beat frequency in cell cultures - exemplary measurements under Pelargonium sidoides extract (EPs 7630). Phytomedicine 2005; 12:46-51.

13 Lizogub VG, et al: Efficacy of a Pelargonium sidoides preparation in patients with the common cold: a randomized, double-blind, placebocontrolled clinical trial. Explore 2007;3:573-584.

14 Matthys $\mathrm{H}$, et al: Efficacy and safety of an extract of Pelargonium sidoides (EPs 7630) in adults with acute bronchitis. Phytomedicine 2003;10(suppl 4):7-17.

15 Matthys $\mathrm{H}$, et al: Pelargonium sidoides preparation (EPs ${ }^{\circledR} 7630$ ) in the treatment of acute bronchitis in adults and children. Phytomedicine 2007;14(suppl 6):69-73.

16 Haidvogl M, Heger M: Treatment effect and safety of EPs ${ }^{\circledR} 7630$-solution in acute bronchitis in childhood: report of a multicentre observational study. Phytomedicine 2007;14(suppl 6): 60-64.

17 Matthys H, Heger M: Treatment of acute bronchitis with a liquid herbal drug preparation from Pelargonium sidoides roots (EPs 7630): a randomised, multicentre, double-blind, placebo-controlled study. Curr Med Res Opin 2007;23:323-331.

18 Matthys H, Heger M: EPs ${ }^{\circledR} 7630$-solution - an effective therapeutic option in acute and exacerbating bronchitis. Phytomedicine 2007;14(suppl 6):65-68.

19 Matthys H, Funk P: EPs 7630 improves acute bronchitic symptoms and shortens time to remission - results of a randomised, doubleblind, placebo-controlled, multicentre trial. Planta Med 2008;74:686-692.

20 Kamin W, et al: Efficacy and tolerability of EPs 7630 in children and adolescents with acute bronchitis: a randomized, double-blind, placebocontrolled multicenter trial with a herbal drug preparation from Pelargonium sidoides roots. Int J Clin Pharmacol Ther 2010;48:184-191.

21 Kamin W, et al: Efficacy and tolerability of EPs 7630 in patients (aged 6-18 years old) with acute bronchitis: a randomized, double-blind, placebo-controlled clinical dose-finding study. Acta Paed 2010;99:537-543.
22 Kamin W, et al: Treatment of acute bronchitis with EPs 7630: randomized, controlled trial in children and adolescents. Ped Int 2012;54:219226.

23 Matthys $\mathrm{H}$, et al: Pelargonium sidoides bei akuter Bronchitis - gesundheitsbezogene Lebensqualität und Therapiebeurteilung aus Patientensicht unter Behandlung mit EPs 7630. Wien Med Wochenschr 2010;160:564-570.

24 Matthys H, et al: Efficacy and tolerability of EPs 7630 tablets in patients with acute bronchitis: a randomised, double-blind, placebo-controlled dose-finding study with a herbal drug preparation from Pelargonium sidoides. Curr Med Res Opin 2010;26:1413-1422.

25 Bachert C, et al: Treatment of acute rhinosinusitis with the preparation from Pelargonium sidoides EPs 7630: a randomized, double-blind, placebocontrolled trial. Rhinology 2009;47:51-58.

26 Schapowal A, Heger M: EPs ${ }^{\circledR} 7630$ Lösung (Umckaloabo ${ }^{\circledR}$ ) bei Sinusitis. Z Phytother 2007; 28:58-65.

27 Bereznoy VV, et al: Efficacy of extract of Pelargonium sidoides in children with acute nongroup a beta-hemolytic streptococcus tonsillopharyngitis: a randomized, double-blind, placebo-controlled trial. Altern Ther Health Med 2003;9:68-79.

28 Patiroglu T, et al: The efficacy of Pelargonium sidoides in the treatment of upper respiratory tract infections in children with transient hypogammaglobulinemia of infancy. Phytomedicine 2012;19:958-961.

29 Lehrl S, et al: The BSS - a valid clinical instrument to measure the severity of acute bronchitis. J Lung Pulm Respir Res 2014;1:00016.

30 Agbabiaka TB, et al: Pelargonium sidoides for acute bronchitis: a systematic review and metaanalysis. Phytomedicine 2008;15:378-385. Erratum in: Phytomedicine 2009;16:798-799.

31 Timmer A, et al: Pelargonium sidoides extract for treating acute respiratory tract infections. Cochrane Database Syst Rev 2013;10:CD006323.

32 Matthys H, et al: Safety and tolerability of EPs 7630 in clinical trials. Adv Pharmacoepidemiol Drug Saf 2013;2:142. 